\title{
Diffusion of scientific concepts on obesity in the global context: a historical review
}

\author{
Difusão de conceitos científicos sobre \\ obesidade no contexto mundial: \\ análise histórica
}

Francisco de Assis Guedes de VASCONCELOS ${ }^{1}$ (iD) 0000-0002-6162-8067

This article aimed to carry out a historical analysis of the dissemination of the scientific concepts on obesity, overweight and excess weight in the field of nutritional epidemiology in the world. The methodological procedures comprised: (1) Systematic search in the PubMed ${ }^{\circledR}$ database using single keywords and without date filter; (2) Documentary analysis of normative instruments on the websites of the World Health Organization, the Centers for Disease Control and Prevention and the World Obesity Federation; and (3) Analysis of the scientific production of scientists participating in the obesity classification of the International Obesity Task Force. The historical analysis showed that, considering the volume of publications on obesity, it appears that in the 1940-1949 decade the problem of obesity emerged on the world scenario. From the number of publications issued in the last 20 years, which corresponds to $85 \%$ of the investigated period, we can deduct that scientists' concern to investigate the subject as a phenomenon coincides with the World Health Organization declaration of obesity as a global epidemic issued in the year 2000. In accordance with normative procedures established by international organizations, there has been a hegemonic use of the concepts of obesity and overweight, in this order of priority, by scientists worldwide. The concept of excess weight has experienced a relative rise since the year 2000, but its use has been very restricted, expressing dissonance in face of the recommendations of international standardization organizations, a fact that suggests discussion and review of its use by the world scientific community.

Keywords: Adolescent. Child. Obesity. Overweight. Review.

\section{RE S U M O}

O artigo teve por objetivo realizar uma análise histórica da difusão dos conceitos científicos sobre obesidade, sobrepeso e excesso de peso no campo da epidemiologia nutricional no contexto mundial. Os procedimentos metodológicos 1 Universidade Federal de Santa Catarina, Centro de Ciências da Saúde, Programa de Pós-Graduação em Nutrição. Campus Universitário
Reitor João David Ferreira Lima, s/n., Bloco C, $2^{\circ}$ andar, 88040-900, Florianópolis, SC, Brasil.

How to cite this article

Vasconcelos FAG. Diffusion of scientific concepts on obesity in the global context: a historical review. Rev Nutr. 2021;34:e200166. https://doi.org/10.1590/1678-9865202134e200166 
compreenderam: (1) Busca sistemática na base PubMed ${ }^{\circledR}$ utilizando unitermos isolados e sem filtro temporal para data; (2) Busca e análise documental de instrumentos normativos nas páginas eletrônicas da Organização Mundial de Saúde, do Centers for Disease Control and Prevention e da World Obesity Federation e (3) Análise da produção científica de cientistas participantes da classificação de obesidade da International Obesity Task Force. A análise histórica mostrou que, pelo volume de publicações sobre obesidade, a emergência da problemática no cenário universal ocorreu na década de 1940-1949. Pelo número de publicações dos últimos 20 anos, que corresponde a 85\% do período investigado, pode- se deduzir que a preocupação dos cientistas em investigar a temática é um fenômeno coincidente com a declaração de obesidade como epidemia global feita pela Organização Mundial de Saúde no ano 2000. Em concordância com procedimentos normativos estabelecidos pelas organizações internacionais, verificou-se uma hegemonia do uso dos conceitos de obesity e overweight, nessa ordem de prioridade, pelos cientistas no contexto internacional. O conceito de excess weight experimentou relativa ascensão desde os anos 2000, mas teve seu uso bem restrito, expressando dissonância frente às recomendações das organizações internacionais de normatização - o que sugere uma discussão e revisão de seu uso pela comunidade científica global.

Palavras-chave: Adolescentes. Crianças. Obesidade. Sobrepeso. Revisão.

\section{NTRODUCTION}

According to the World Health Organization (WHO), the global prevalence of obesity almost tripled between 1975 and 2016. In 2016, 650 million adults (13\% of the world population) and more than 124 million children and adolescents 5 to 19 years old (6\% girls and $8 \%$ boys) were obese [1]. In 2019, it was estimated that 38.2 million children under 5 years of age presented with overweight or obesity in the world scenario. The consequences most often associated with these prevalence rates, in line with the WHO, are cardiovascular disease, diabetes; musculoskeletal disorders and some cancers [1].

Epidemiological evidence accumulated in the last decade has confirmed the definition of obesity as a disease of complex and multifactorial origin, involving the interaction of biological, genetic, behavioral, socioeconomic and environmental dimensions [2-6]. To the detriment of this broader conception, there is a hegemonic tendency to adopt an obesity concept restricted to the biological or biomedical paradigm. World Health Organization, for example, when adopting the definition of obesity as the abnormal or excessive accumulation of body fat that can be harmful to health seems to corroborate with this reductionist perspective [1]. Thus, for that regulatory health agency whose actions are carried out in the world context, obesity can be defined based on anthropometric and nutritional parameters considered abnormal, when compared with reference standards that vary according to age, gender, genetic or cultural origin. For the adult population, for example, obesity is defined as a Body Mass Index (BMI) equal to or greater than $30 \mathrm{~kg} / \mathrm{m}^{2}$ [1].

It is noteworthy that the literature that addresses the history of the concept of obesity, except for the distinct and often conflicting interpretative matrices, is consensual in pointing out that the concept has been known since Prehistory or for others since the Ancient Age. However, the concept closer to the current one, which will be the object of assessment in this article, which focuses on the biomedical paradigm, and which defines it based on anthropometric parameters, is much more contemporary [1]. For some scholars, the scientific concept of obesity has been built from the defenses of academic theses at the end of the $16^{\text {th }}$ century and from medical monographs published in the $18^{\text {th }}$ century; however, it was the development of a set of disciplines or biological and life sciences, that occurred in the $19^{\text {th }}$ century, which made it possible to produce the current concept recommended by WHO [2-14].

In the academic field, within the global context, including in Brazil, the diffusion of this biomedical concept based on BMI values has generated the use of several concepts related to obesity, such as the concepts of "overweight", "overweight/obesity", "overweight including obesity" and "excess weight" $[4,5,7,9-19]$. The use of these concepts does not always occur properly and in accordance with the normative procedures recommended by WHO which raises the need for debate and reflection [1]. 
This article aimed to carry out a historical review of the dissemination of the scientific concepts of obesity, overweight and excess weight in the field of nutritional epidemiology in the global context $[2,7,8,20,21]$. Three guiding questions contributed to the establishment of methodological procedures aimed at achieving this objective: (1) What is the historical trajectory of the dissemination of the scientific concepts of obesity, overweight and excess weight? (2) Which concepts of obesity are adopted by health regulatory agencies? (3) What concepts of obesity are adopted by scientists linked to the field of nutritional epidemiology? [22].

\section{METHODS}

The methodological procedures for assessing the diffusion of the concepts of obesity, overweight and excess weight, comprised: (1) Systematic search in the PubMed ${ }^{\circledR}$ basis; (2) Search and documentary analysis of normative instruments on the WHO websites, the Centers for Disease Control and Prevention (CDC) and the World Obesity Federation; and (3). Review of the scientific production of three scientists participating in the obesity classification of the International Obesity Task Force (IOTF).

Initially, the definitions of the three categories under analysis were searched: obesity, overweight and excess weight. Two organization systems of descriptors for thematic search strategies in the field of health were retrieved: Medical Subject Headings (MeSH) and Health Sciences Descriptors (DeSC) [23,24]. Chart 1 shows the localized definitions, emphasizing, as of now, that the descriptor excess weight is not registered in both systems and the other categories present common definitions for both.

The bibliographic search in PubMed ${ }^{\circledR}$ was carried out on September 5, 2020, using the keywords alone and without delimitation of the publication date's temporal filter. This initial methodological procedure, using the keyword "obesity" as an example, was operationalized from the following search path: "obesity" [MeSH Terms] OR "obesity" [All Fields]. Reiterating that for the "excess weight" keywords, the path used was "Excess weight" [All Fields], since it is not registered in the MeSH system. Then, starting with the obesity keyword, a search was carried out with personalized periods of publication date, following the path used

Chart 1 - Definitions of analysis categories obesity, overweight and excess weight pursuant the Medical Subject Headings and Descritores em Ciências da Saúde.

\begin{tabular}{|c|c|c|}
\hline Keyword & MeSH Definition & DeSC Definition \\
\hline Obesity & $\begin{array}{l}\text { A status with BODY WEIGHT that is grossly above } \\
\text { the acceptable or desirable weight, usually due } \\
\text { to accumulation of excess FATS in the body. The } \\
\text { standards may vary with age, gender, genetic or } \\
\text { cultural background. In the BODY MASS INDEX, a } \\
\text { BMI greater than } 30.0 \mathrm{~kg} / \mathrm{m}^{2} \text { is considered obese, and } \\
\text { a BMI greater than } 40.0 \mathrm{~kg} / \mathrm{m}^{2} \text { is considered morbidly } \\
\text { obese (MORBID OBESITY). }\end{array}$ & $\begin{array}{l}\text { A status with BODY WEIGHT that is grossly above the } \\
\text { acceptable or desirable weight, usually due to accumulation } \\
\text { of excess FATS in the body. The standards may vary with } \\
\text { age, gender, genetic or cultural background. In the BODY } \\
\text { MASS INDEX, a BMI greater than } 30.0 \mathrm{~kg} / \mathrm{m}^{2} \text { is considered } \\
\text { obese, and a BMI greater than } 40.0 \mathrm{~kg} / \mathrm{m}^{2} \text { is considered } \\
\text { morbidly obese (MORBID OBESITY). }\end{array}$ \\
\hline Overweight & $\begin{array}{l}\text { A status with BODY WEIGHT that is above certain } \\
\text { standard of acceptable or desirable weight. In the } \\
\text { scale of BODY MASS INDEX, overweight is defined } \\
\text { as having a BMI of } 25.0-29.9 \mathrm{~kg} / \mathrm{m}^{2} \text {. Overweight may } \\
\text { or may not be due to increases in body fat (ADIPOSE } \\
\text { TISSUE), hence overweight does not equal "over fat". }\end{array}$ & $\begin{array}{l}\text { A status with BODY WEIGHT that is above certain } \\
\text { standard of acceptable or desirable weight. In the } \\
\text { scale of BODY MASS INDEX, overweight is defined as } \\
\text { having a BMI of } 25.0-29.9 \mathrm{~kg} / \mathrm{m}^{2} \text {. Overweight may or may } \\
\text { not be due to increases in body fat (ADIPOSE TISSUE), } \\
\text { hence overweight does not equal "over fat". }\end{array}$ \\
\hline Excess weight & $\begin{array}{l}\text { Excess weight: No items found } \\
\text { Excess body weight: No items found. }\end{array}$ & $\begin{array}{l}\text { The descriptor excess weight was not found. } \\
\text { Sorry, the descriptor excess body weight was not found. See } \\
\text { another word or change the DESCRIPTORS' LANGUAGE. }\end{array}$ \\
\hline
\end{tabular}

Note: DecS: Descritores em Ciências da Saúde [24]; Health Sciences Descriptors MeSH: Medical Subject Headings [23]. 
to capture articles published in the last ten years: ("obesity" [MeSH Terms] OR "obesity" [All Fields]) AND ("2010/01/01" [PDat]: "2020/05/09" [PDat]). The search was organized according to decreasing decades until the article with the oldest publication date was found. The total number of captured articles was included in the analysis without applying exclusion criteria; the results are presented in absolute numbers and percentages in Table 1. The analysis of the articles was also organized by decades, from the identification of the first published article with the key word obesity. In each decade investigated, an analysis was carried out in order to identify in the publications which definitions and methodological criteria were used for the referred keywords.

Table 1. Distribution of the absolute number and percentage of articles published in PubMed ${ }^{\circledR}$ according to the key words obesity, overweight, overweight and obesity, and excess weight, in September 5, 2020.

\begin{tabular}{|c|c|c|c|c|c|c|c|c|}
\hline \multirow{3}{*}{ Years } & \multicolumn{8}{|c|}{ Keywords } \\
\hline & \multicolumn{2}{|c|}{ Obesity } & \multicolumn{2}{|c|}{ Overweight } & \multicolumn{2}{|c|}{ Overweight and obesity } & \multicolumn{2}{|c|}{ Excess weight } \\
\hline & $\mathrm{N}$ & $\%$ & $\mathrm{~N}$ & $\%$ & $\mathrm{~N}$ & $\%$ & $\mathrm{~N}$ & $\%$ \\
\hline $2010-2020$ & 204,930 & 60.9 & 139,255 & 56.5 & 125,488 & 55.4 & 3,698 & 68.9 \\
\hline 2000-2009 & 77,412 & 23.0 & 61,124 & 24.8 & 56,343 & 24.9 & 1,195 & 22.3 \\
\hline 1990-1999 & 23,377 & 6.9 & 18,103 & 7.3 & 16,919 & 7.5 & 318 & 5.9 \\
\hline 1970-1979 & 10,252 & 3.0 & 9,737 & 3.9 & 9,609 & 4.2 & 25 & 0.5 \\
\hline 1960-1969 & 4,894 & 1.5 & 4,849 & 2.0 & 4,836 & 2.1 & 12 & 0.2 \\
\hline 1950-1959 & 1,729 & 0.5 & 1,729 & 0.7 & 1,718 & 0.8 & 3 & 0.05 \\
\hline 1940-1949 & 253 & 0.1 & 244 & 0.1 & 242 & 0.1 & - & - \\
\hline 1930-1939 & 35 & 0.01 & 1 & 0.005 & - & - & - & - \\
\hline $1920-1929$ & 25 & 0.01 & 1 & 0.005 & - & - & - & - \\
\hline 1910-1919 & 8 & 0.002 & - & - & - & - & - & - \\
\hline 1900-1909 & 10 & 0.003 & - & - & - & - & - & - \\
\hline 1890-1899 & 6 & 0.002 & - & - & - & - & - & - \\
\hline 1880-1889 & 3 & 0.001 & - & - & - & - & - & - \\
\hline Total & 336,528 & 100.0 & 246,573 & 100.0 & 226,425 & 100.0 & 5,370 & 100.0 \\
\hline
\end{tabular}

The search on the websites of WHO, CDC and the World Obesity Federation was carried out on June 5, 2020 aiming to locate and perform documentary analysis of normative instruments that would make it possible to identify evidence of the adoption and/or dissemination of the use of the analytical categories investigated by such agencies. Analysis of the normative instruments sought to answer the following questions: (1) What concepts of obesity are adopted by these agencies for standardizing health actions? and (2) What nutritional diagnosis criteria (indexes, cut-off points and reference patterns) of the analyzed categories (obesity, overweight and excess weight) are adopted by these agencies?

The analysis of publications by scientists associated to the field of nutritional epidemiology of obesity, in the global context, occurred based on an intentional selection process [20-21]. We opted to investigate the publications of scientific articles by three of the scientists involved (Tim James Cole, William H. Dietz and Katherine Mayhew Flegal), in the years 2000, in the elaboration of the classification of obesity for children and adolescents from 2 to 18 years of age adopted by the IOTF [25]. One of the four authors involved in that publication had not present publications on the subject in the last ten years, therefore being excluded from the review process [25]. The search for articles by these three scientists was done via PubMed ${ }^{\circledR}$ database, on May 12, 2020 following the example: Cole, Tim [Full Author Name] AND ("01/01/2010" [PDat]: "2020/05/12 "[PDat]), which makes it possible to capture articles published in the last ten years. The search was carried 
out in order to make it possible to capture the universe of publications of the three authors on that base and further analysis and identification of those bases using the investigated key words: obesity, overweight and excess weight. A short synthesis of the publication history of the three authors was performed organized for decades, from the identification of the first published article with the investigated theme. In each decade investigated, an analysis was carried out in order to identify in the publications which definitions and criteria were used by the three investigated authors for the referred keywords.

\section{DIFFUSION OF CONCEPTS ABOUT OBESITY, OVERWEIGHT AND EXCESS WEIGHT BYREGULATORY AND LEGITIMACY AGENCIES WORLDWIDE}

The review of the WHO documents carried out in the present study indicates that this agency, responsible for the standardization of health actions in the global context, has adopted, over the years, a conception of obesity centered on the biomedical paradigm [2].

Recent access to the WHO website made it possible to confirm the dissemination by this institution of the categories overweight and obesity, defining them as the abnormal or excessive accumulation of body fat that can be harmful to health [1]. According to the WHO, the definition of overweight and obesity is based on the application of anthropometric indicators, such as the Body Mass Index (BMI), used in the nutritional diagnosis of adults, children and adolescents between 5 and 19 years of age [1]. Chart 2 shows the current definitions of overweight and obesity for adults, children and adolescents between 5 and 19 years of age and children under five years of age [1].

Seeking to map the use trajectory of the concepts of overweight and obesity by the WHO, retrieving a publication dated 1995, it is observed that, at that time, the nutritional classification of adults, based on the use of BMI, used only the overweight term [26]. Thus, three cutoff points in the BMI were recommended for the classification of adults: $25-29.99 \mathrm{~kg} / \mathrm{m}^{2}$ corresponded to overweight grade l; $30-39.99 \mathrm{~kg} / \mathrm{m}^{2}$ was equivalent to overweight grade II; and $\geq 40 \mathrm{~kg} / \mathrm{m}^{2}$ expressed overweight grade III [26].

It is noteworthy, however, that in a WHO publication issued in the year 2000, there is the adoption of a BMI classification for adults different from the current one shown in Chart $2[1,27]$. In that publication the overweight category corresponded to a BMI $\geq 25 \mathrm{~kg} / \mathrm{m}^{2}$; preobese meant a BMI between 25 and 29.99kg/m²; obese class I was equivalent to a BMI between 30 and $34.99 \mathrm{~kg} / \mathrm{m}^{2}$, obese class II expressed a BMI between 35 and $39.99 \mathrm{~kg} / \mathrm{m}^{2}$; and obese class III portrayed a BMI $\geq 40 \mathrm{~kg} / \mathrm{m}^{2}$.

The recommendations of the CDC, the regulatory body of health actions in the United States of America go in the same current WHO direction [1]. For the adult population, the CDC adopts the same

Chart 2 - Definitions of Overweight and Obesity for adults, children and adolescents aged 5-19 and children under five, according to the World Health Organization.

\begin{tabular}{|c|c|c|}
\hline Varibles & Overweight & Obesity \\
\hline Adults (both genders) & $\begin{array}{l}\text { Is a body mass index equal to or greater than } \\
25\left(\mathrm{~kg} / \mathrm{m}^{2}\right) \text {. }\end{array}$ & $\begin{array}{l}\text { Is a body mass index equal to or greater than } \\
30\left(\mathrm{~kg} / \mathrm{m}^{2}\right) \text {. }\end{array}$ \\
\hline Children under 5 years of age & $\begin{array}{l}\text { Is a weight-for-height index }(\mathrm{W} / \mathrm{H}) \text { greater than } \\
2 \text { standard deviations above the median of the } \\
\text { WHO growth reference. }\end{array}$ & $\begin{array}{l}\text { Is a weight-for-height index }(\mathrm{W} / \mathrm{H}) \text { greater than } \\
3 \text { standard deviations above the median of the } \\
\text { WHO growth reference. }\end{array}$ \\
\hline
\end{tabular}


definitions of overweight and obesity recommended by the WHO [1]. For children and adolescents, although similar, the definitions released on the institution's website are based on specific methodological procedures. Therefore, overweight is defined as a BMI equal to or greater than the 85th percentile and below the $95^{\text {th }}$ percentile of the growth pattern of American children and adolescents of the same age and gender. Obesity, in turn, is defined as a BMI equal to or greater than the 95th percentile of the growth pattern for American children and adolescents of the same age and gender [28].

The current World Obesity Federation, a charitable civil entity based in the United Kingdom, which brings together more than 50 national and regional associations dedicated to the study and intervention on obesity, gathering different professional categories that work in this field of knowledge, also follows the adoption and dissemination of overweight and obesity concepts, in agreement with the WHO and CDC concepts $[1,28]$. Since its creation in 1967, this Federation has been responsible for organizing scientific events, editing scientific journals and other actions covering the obesity issue on the international scenario. The World Obesity Federation sustains the view that obesity is a chronic disease - a medical condition described as excess body weight in the form of fat, and when accumulated, that fat can lead to serious health problems. That organization adopts the classification based on BMI, considering, for example, in adults, overweight or pre-obesity, defined as a BMl of 25 to $29.9 \mathrm{~kg} / \mathrm{m}^{2}$, while a BMl $\geq 30 \mathrm{~kg} / \mathrm{m}^{2}$ defines obesity [29].

Therefore, these three regulatory and legitimizing agencies of global health actions adopt and disseminate in their normative instruments conceptions about obesity based essentially on the biomedical or anthropometric-nutritional paradigm [2]. Although some of the normative instruments allude to the multidimensional and complex nature of obesity, in the definitions of overweight and obesity adopted, the biological bias predominates [2-6]. The concept of excess weight, in turn, was not found in the normative instruments investigated in these three institutions.

It is worth underscoring the multiple, complex and conflicting interests that mediate the adoption of this dominant paradigm by these three international agencies, a fact that does not mean disregarding the existence and relevance of other counter-hegemonic approaches or paradigms in the field of obesity epistemology, such as the socio-cultural or anthropological and psychological/behavioral perspective [30-36]. In general, psychological/behavioral approaches seek to understand obesity from subjective, individual, particular parameters of each case, not holding on generalizations, nor on clinical, quantitative parameters, based on population means (reference standard) [33-36]. In turn, socio-cultural approaches seek to emphasize that the structural, economic, environmental, political and socio-cultural dimensions play a greater explanatory role in opposition to the biological and/or behavioral perspectives of obesity [30-32].

\section{K NOWLEDGE PRODUCTION AND DISSEMINATION ABOUT OBESITY, OVERWEIGHT AND EXCESS WEIGHT BY SCIENTISTS IN THE INTERNATIONAL CONTEXT}

In the review of the publications of the three scientists bound to the field of obesity nutritional epidemiology, in the world context, we started from the understanding that scientific concepts obey a logic of historical-social construction, which is mediated by the inter-relationship of multiple interests existing in each historical moment in which they are created, reviewed, deconstructed and/or reconstructed [20-21]. Therefore, in order to support this methodological option, the conceptions of Pierre Bourdieu's [37] scientific field and capital conceptions and Thomas Kuhn's scientific community and paradigm were adhered to [38]. 
Thus, the scientific concepts that constitute the objects of study in this article are close to the Kuhnian's paradigm conception, defined as a universally recognized scientific achievement that, for some time, provides problems and model solutions for a community of science practitioners - the scientific community [38]. For Kuhn, practitioners (scientists) are subjected to a similar process of initiation and professional training, absorbing the same technical literature and drawing many of the same lessons from it [38]. Similarly, they come close to the concepts originating from Bourdieu, who conceived the scientific field as a particular market characterized by the competitive struggle waged between scientists and/or scientific institutions over the possession of scientific capital - a kind of symbolic capital, not monetary, and which becomes a scientific authority or scientific competence for science practitioners [37].

As we have already indicated, the three scientists investigated, belonging to three different scientific institutions, shared in the year 2000, the publication of an article presenting the results of a research for the construction of percentile distribution curves of cut-off points specific to BMI for age and gender of children and adolescents aged 2 to 18 years, focused on the nutritional diagnosis of overweight and obesity. This is an investigation that gathered data from cross-sectional studies with representative samples from Brazil, Singapore, United States of America, Great Britain, Holland and Hong Kong [25]. It is emphasized that at that time, twenty years ago, due to the magnitude and severity of obesity prevalence and its consequences, this condition was declared by the WHO as a global epidemic [27]. Until then, while the debate around the assessment of nutritional status of adolescents was intense, the publication of this article by Cole et al. became an important paradigm for scientists in the field of nutritional epidemiology of obesity [25].

Tim James Cole's academic career (Great Ormond Street Institute of Child Health, University College London, UK) in the field of childhood obesity epidemiology began in the decade 1970-1979, when his first studies were published using the concepts of overweight and obesity. It should be noted that in an article published in 1978, the anthropometric assessment of 203 children under five years of age and their mothers was based on the methodology of weight adequacy in relation to height (percentage of expected weight), in force in those circumstances [39]. Thus, both children and mothers were classified as underweight if the expected weight was less than 90\% adequate, normal weight if a $90-110 \%$ adequacy resulted, and overweight if an adequacy above 110\% was obtained [39]. In the 1980-1999 decades, an expressive academic production by this scientist is observed, with emphasis of papers on growth and development patterns, use of BMI, skin folds and other anthropometric measures and the approach of the LMS method [40]. In the 2000-2010 decade, his participation in the construction of the classification of obesity adopted by the IOTF should be emphasized [25]. Then, Cole et al. in 2007 published an article on specific cutoff points for BMI by age and gender, population aged 2 to 18 years, aiming at the classification of malnutrition. In the search carried out, a total of 616 titles by this author were captured, 112 of which were associated with the term obesity [41]. In the last two years (2018-2020), there has been continued use of the terms overweight and obesity $[42,43]$.

The scientific production of William H. Dietz (Division of Nutrition and Physical Activity of the CDC, Milken Institute School of Public Health, USA) in the field of childhood obesity epidemiology began in the 1980-1989 decade, when his first articles were published where the concept of obesity circulated [44]. In the 1990-1999 decade, the overweight concept began to appear in his articles, defined as a BMI above the $95^{\text {th }}$ percentile for age and gender of the North American reference standard [45]. In the 2000-2010 decade, his academic production was expanded, characterized by the maintenance of the use of the concepts of obesity and overweight [25]. A total of 240 titles by this author were captured, 179 of which were associated with the term obesity. In recent years, this author has remained faithful to the use of the concepts of obesity and overweigh in his scientific publications [12-46]. 
Katherine Mayhew Flegal (Stanford Prevention Research Center, Department of Medicine, Stanford University School of Medicine, Stanford, CA, USA) began her academic career in the 1980-1989, but her publications in the field of obesity epidemiology only gained expression in the decade 1990-1999. In an article published in 1993, a literature review, she concluded that until then there was no objective and consensual definition of obesity for children and adolescents [47]. In general, in the articles of that decade, for the classification of adults, Flegal adopted the use of overweight defining it as a BMI $\geq 25 \mathrm{~kg} / \mathrm{m}^{2}$ and obesity defined as a $\mathrm{BMI} \geq 30 \mathrm{~kg} / \mathrm{m}^{2}$; for adolescents overweight was defined by the 95 th percentile of the age and gender specific BMI of the National Health Examination Survey (NHES) II and III [48]. In an article published in March 2000, the introduction of the concept of "pre-obesity" is identified in her publications. In that article, the adult population is investigated based on a WHO recommendation, which, in that context, classified as underweight (BMI $\left.<18.5 \mathrm{~kg} / \mathrm{m}^{2}\right)$, normal weight (BMI $\geq 18.5$ to $24.9 \mathrm{~kg} / \mathrm{m}^{2}$ ), pre-obesity $\left(\mathrm{BMI} \geq 25\right.$ to $\left.29.9 \mathrm{~kg} / \mathrm{m}^{2}\right)$ and obesity $\left(\mathrm{BMI} \geq 30 \mathrm{~kg} / \mathrm{m}^{2}\right)[27,49]$. In the last decade, the author continued with a significant volume of academic production, publishing articles with reflexions approaches, as well as reaffirming the scientific use of the overweight and obesity concepts [50,51]. In an article published in 2018 she keeps using the WHO classification of the 2000s: underweight (BMI $<18.5 \mathrm{~kg} / \mathrm{m}^{2}$ ), normal weight $\left(\mathrm{BMI} \geq 18.5\right.$ to $\left.24.9 \mathrm{~kg} / \mathrm{m}^{2}\right)$, overweight $\left(\mathrm{BMI} \geq 25\right.$ to $\left.29.9 \mathrm{~kg} / \mathrm{m}^{2}\right)$ and grade I obesity (BMI $\geq 30$ to $34.9 \mathrm{~kg} / \mathrm{m}^{2}$ ) and obesity grade $\mathrm{II+III}\left(\mathrm{BMI} \geq 35 \mathrm{~kg} / \mathrm{m}^{2}\right)[27,52]$. Over the period 1980 to 2020,175 titles by this author were captured, 103 of which were associated with the concept of obesity.

The analysis of the publications of the three scientists shows a communion of the biomedical paradigm and the exclusive use of the concepts of overweight and obesity, with the overweight/obesity and overweight including obesity variants still circulating in her articles, without any use of the concept of excess weight [2]. The analysis also denotes the intellectual organicity of publications with the investigated normatization and legitimacy agencies: WHO, CDC and World Obesity Federation.

\section{THE DIFFUSION OF CONCEPTS ABOUT OBESITY, OVERWEIGHT AND EXCESS WEIGHT IN THE PUBMED ${ }^{\circledR}$ ELECTRONIC BASE}

The search for the obesity concept yielded the capture of 336,528 titles published between 1880 and May 9, 2020, as shown in Table 1. In the 1880s, three publications were captured $(0.001 \%$ of the total identified); however, only the full texts of two articles were available. The first record, published in April 1880, is a three-page case report, in which the author describes the results of an autopsy performed on an obese man aged 50 years from the city of Newcastle, England [53]. The second record, released in May 1885, is a brief letter from the author reporting anthropometric measurements of a fifteen-monthold child considered to be with "excessive obesity" [54]. These two short initial reports have in common the concept qualification procedure - extreme obesity and excessive obesity, in addition to the allusion to the use of anthropometric measures (weight, height, chest circumference, abdomen, arm and leg) as diagnostic criteria for the quantity and distribution of body fat. Therefore, in these reports from the 1880s, the proximity to the contemporary biomedical paradigm, centered on BMI may be observed [1].

Until the 1930-1939 decade, the number of records with the term obesity was relatively small (Table 1). In the years 1930-1939, three articles stand out that recall historical aspects of the process of production and diffusion of the obesity concept in the world scenario. Such articles already presented definitions of obesity as a disease, characterized by the excessive storage of body fat, associated with excess food intake in relation to its organic use. They also described methodological procedures for anthropometric measurements of weight and height, associated with age and gender, for the construction of indicators 
of ideal weight adequacy and classifications using the concepts of overweight and obesity [55]. The Lyon's definition of obesity published in 1931, "obesity might be defined as an excessive storage of fat, resulting from a surplus of food intake over food utilization" [55], except, to the best of our knowledge, it reappears resignified and without any credit to contemporary normative WHO texts [1].

From the 1940-1949 decade, the number of publications captured began to gain importance, but corresponded to only $0.1 \%$ (Table 1). An article published in 1946 stands out, presenting tables of ideal weight distribution for age, obesity classification and results of an association study between degrees of obesity and mortality [56].

In the period 1950-1959, the volume of publications corresponded to $0.5 \%$ of the total captured, with the emergence of studies identifying an association of obesity with other chronic Non-Communicable Diseases (NCDs) (diabetes, hypertension, cardiovascular diseases) [57]. Between 1960-1969 (with only 1.5\% of the publications captured), as studies progressed indicating an increase in worldwide prevalence, as well as pointing out evidence of an association with NCDs and mortality rates, so did those on causality, diagnosis and classification of obesity [58]. In the 1970s and 1980s, the percentage of publications was 3.0 and 4.0, respectively, with a trend in an increase in the number of articles showing an association between obesity and NCDs and the intensification of studies on new diagnostic procedures based on anthropometric measurements [59]. In the years1990-1999, 6.9\% of the total number of articles were captured using the key word obesity, with an increase since then. In the 2000-2009 interval, articles using the obesity key word corresponded to $23 \%$ of the total captured. In the last ten years; however, a higher percentage of publications was found (60.9\% of the total titles published in the period from 1880 to May 2020), indicating the magnitude, severity and updating of the problem in the world context [60-63] (Table 1).

The search results for the categories overweight and overweight and obesity, according to Table 1, showed very similar behaviors, both in the total number of publications captured and in the distribution per decade investigated. Only in the 1980s did the term overweight begin to be used more frequently in the publications titles. Similar behavior was observed for the spread of the term overweight and obesity, which started to have a circulation frequency in the titles of publications from 1970 [64]. Since the 2000s, with the dissemination of the IOTF obesity classification, the use of the term overweight including obesity has been circulating in publications, a practice observed until today $[25,65]$. Another variant concept that has been circulating since the 2000s to the present is overweight/obesity, including in Brazil [17-19,66-68].

The search for the excess weight category captured a total of 5,370 publications. The first articles were located in the 1950-1959 period. From 1980-1989, the number of articles began to increase, but corresponded to only $2.1 \%$ of the total publications of the period analyzed (Table 1). The first three articles were published in November 1954, April 1955 and December 1957; they do not have complete texts available in the database, but by analyzing the titles and abstracts of the first two papers, it appears that they were captured on account of the expression "excess weight gain", denoting a different meaning from the excess weight category, the object of this investigation.

In fact, the category excess weight with a meaning close to that used today, began to circulate on this basis during 1960-1969, when PubMed ${ }^{\circledR}$ recorded the capture of 12 publications (only $0.2 \%$ of the total captured in the period), offering the full text of three papers (Table 1). In May 1960, an article was published reporting the results of a retrospective cohort study with anthropometric data of schoolchildren, collected when they were 10 to 13 years old, and assessed 20 years later, in the city of Hagerstown, Maryland, USA [69]. It was noted that throughout the text, from the title to the conclusions, the authors used the terms excess weight, obesity, overweight and excess weight status [69].

In the 1970s, the analysis of articles with full texts available showed that the use of the term excess weight was made to express, at times, the feeling of "excess weight gain", and other times, to express 
a category resulting from the application of the "ideal weight range adequacy" methodology, like in the article published in 1973 [70]. In the 1980s, the analysis of articles that used excess weight showed that the majority continued to apply the methodological procedures of \% adequacy of the ideal weight or to express excess weight gain. In the period 1990-1999, there was a predominance of articles related to the treatment of morbid obesity, also using definitions based on the \% adequacy of the ideal weight. We emphasize the capture of one of the first articles using the expression "excess body weight" defined with a BMl $>25 \mathrm{~kg} / \mathrm{m}^{2}$ [71].

Since the 2000s, the circulation of the terms excess weight in the current sense has become more frequent, however, still without a clear explanation of the theoretical frameworks of reasoning and the relevant regulatory agencies. An example can be seen in a study by Faeh et al. [72] published in 2007, with a population of diabetics aged 25-64 years. The classification used was: Underweight=BMl<18.5km/ ${ }^{2}$; excess weight=BMl $\geq 25 \mathrm{~km} / \mathrm{m}^{2}$; obesity=BMl $\geq 30 \mathrm{~kg} / \mathrm{m}^{2}$; however, the ranking reference source was not reported. In the last 10 years, according to Table 1, it is observed that the use of the term excess weight had the highest frequency of publications (68.9\% of the total volume); yet, based on the review of the articles, this keyword remains circulating without an accurate definition, including in Brazilian journals [17-19,73,74].

From the number of publications captured for the terms obesity, overweight and overweight/obesity in the 1940-1949 years, it can be deduced that this was the decade of the problem of obesity emergence in the world scenario. This was the period involving World War II, also when international organizations focused on the development of international health actions, such as the WHO, emerged [75]. Analysis of the historical trajectory of obesity epidemiology tend to point to the 1980s as the contextual outline of the beginning of the epidemic, a historic moment in which many countries experienced the process of epidemiological and nutritional transition $[3,5,11-14,75]$. From the number of publications in the last 20 years, which corresponds to almost $85 \%$ of the total period investigated, it can be deduced that the concern of scientists in investigating the theme is a phenomenon coinciding with the declaration of obesity as a global epidemic issued by the WHO in the year 2000 [27].

Based on the perspective of the historical-social construction of knowledge [37-38], and instrumentalized by the historical analysis of the scientific literature captured in the PubMed ${ }^{\circledR}$ database, it can be deduced that the current concepts that permeate the central concept of obesity were being produced and accumulated over the period from 1880, when the first studies captured on the investigated base were identified, to the current scenario of the Covid-19 pandemic (November 2020), when evidence emerges of obesity constituting one of the risk factors for complications of this new human disease $[2,7,8,37,38,76,77]$. A limitation of the study was its anchoring in a single electronic database. However, it is noteworthy that PubMed ${ }^{\circledR}$ comprises more than 30 million citations of biomedical literature, involving a wide network of journals in the field of biological sciences, life and health, including Brazilian journals indexed in other databases as well $[4,5,14-19]$. Therefore, a potential bias in the selection of articles on the scientific concepts of obesity could have occurred, since this search tool presents greater identification and proximity to the biomedical paradigm [2]. On the other hand, in the same base, studies were also captured with critical and reflexion content on the hegemony and centrality of this dominant paradigm in the field of nutritional epidemiology of obesity $[2-6,14]$. It is important to emphasize that in the search carried out, the use of the concepts of overweight, obesity and excess weight was detected by authors clearly linked to the socio-cultural paradigm, as well as by others associated with the psychological/behavioral paradigm [30-36].

\section{CONCLUSION}

The historical analysis carried out showed that the volume of production and diffusion of scientific knowledge, investigated based on the concepts of overweight, obesity and excess weight, using one of 
its vehicles for dissemination in the international context (PubMed ${ }^{\circledR}$ journals), denotes the relevance and magnitude that the theme reached in the global scenario, in the last decades of the $20^{\text {th }}$ Century and its expressive acceleration in the first two decades of the $21^{\text {st }}$ Century.

In accordance with the normative procedures related to the definition and classification of obesity, established by international organizations, there was a hegemony in the use of the concepts of obesity, overweight and overweight/obesity, in this order of priority, by scientists in the universal context. The concept of excess weight or excess body weight experienced a relative rise since the 2000s, but its use was very restricted in relation to the others, expressing dissonance in face of the recommendations of international standards organizations, which suggest discussion and review of its use by the world scientific community.

\section{REFERENCES}

1. World Health Organization. Obesity and overweight: key facts. Geneva: World; 2020 [cited 2020 May 6]. Acessed: https://www.who.int/news-room/fact-sheets/detail/obesity-and-overweight

2. Karasu SR. The obesities: an overview of convergent and divergent paradigms. Am J Lifestyle Med. 2016;10(2):84-96. https://doi.org/10.1177/1559827614537773

3. Hruby A, Hu FB. The epidemiology of obesity: a big picture. PharmacoEconomics. 2015;33:673-89. https://doi. org/10.1007/s40273-014-0243-x

4. Francisco LV, Diez-Garcia RW. Abordagem terapêutica da obesidade: entre conceitos e preconceitos. Demetra. 2015;10(3):705-16. https://doi.org/10.12957/demetra.2015.16095

5. Dias PC, Henriques P, Anjos LA, Burlandy L. Obesidade e políticas públicas: concepções e estratégias adotadas pelo governo brasileiro. Cad Saúde Pública. 2017;33(7):e00006016. https://doi.org/10.1590/0102-311X00006016

6. Endalifer ML, Diress G. Epidemiology, predisposing factors, biomarkers, and prevention mechanism of obesity: a systematic review. J Obes. 2020:6134362. https://doi.org/10.1155/2020/6134362

7. Komaroff M. For researchers on obesity: historical review of extra body weight definitions. J Obes. 2016;2016:2460285. https://doi.org/10.1155/2016/2460285

8. Haslam D. Weight management in obesity: past and present. Int J Clin Pract. 2016;70(3):206-17. https://doi. org/10.1111/ijcp.12771

9. Staub K, Bender N, Floris J, Pfister C, Rühli FJ. From undernutrition to overnutrition: the evolution of overweight and obesity among young men in Switzerland since the 19th Century. Obes Facts. 2016;9(4):259-72. https://doi. org/10.1159/000446966

10. Echouffo-Tcheugui JB, Short MI, Xanthakis V, Field P, Sponholtz TR, Larson MG, et al. Natural history of obesity subphenotypes: dynamic changes over two decades and prognosis in the framingham heart study. J Clin Endocrin Metab. 2019;104(3):738-52. https://doi.org/10.1210/jc.2018-01321

11. Gadde KM, Martin CK, Berthoud HR, Heymsfield SB. Obesity: pathophysiology and management. J Am Coll Cardiol. 2018;71(1):69-84. https://doi.org/10.1016/j.jacc.2017.11.011

12. Bray GA, Heisel WE, Afshin A, Jensen MD, Dietz WH, Long $M$, et al. The science of obesity management: an endocrine society scientific statement. Endocr Rev. 2018;39(2):79-132. https://doi.org/10.1210/er.2017-00253

13. Bray GA, Kim KK, Wilding JPH. Obesity: a chronic relapsing progressive disease process. a position statement of the World Obesity Federation. Obes Rev. 2017;18:715-23. https://doi.org/10.1111/obr.12551

14. Paim MB, Kovaleski DF. Análise das diretrizes brasileiras de obesidade: patologização do corpo gordo, abordagem focada na perda de peso e gordofobia. Saúde Soc. 2020;29(1):e190227. https://doi.org/10.1590/S0104-12902020190227

15. Silva CAC, Leite AL, Moreira JA, Abreu DDC, Oliveira PEA, Nunes DP, et al. Association of dyslipidemia, hypertension and overweight/obesity with work shift and duration of employment among police officers in a small town in Northeastern Brazil. Rev Bras Med Trab. 2019;17(4):537-44. https://doi.org/10.5327/Z1679443520190401

16. Matsudo VK, Ferrari GL, Araújo TL, Oliveira LC, Mire E, Barreira TV, et al. Indicadores de nível socioeconômico, atividade física e sobrepeso/obesidade em crianças brasileiras. Rev Paul Pediatr. 2016;34(2):162-70. https://doi. org/10.1016/j.rpped.2015.04.003 
17. Bezerra IN, Alencar ES. Association between excess weight and beverage portion size consumed in Brazil. Rev Saúde Pública. 2018;52:21. https://doi.org/10.11606/s1518-8787.2018052000082

18. Fávaro TR, Ferreira AA, Cunha GMD, Coimbra CEA Jr. Excesso de peso em crianças indígenas Xukuru do Ororubá, Pernambuco, Brasil: magnitude e fatores associados. Cad Saúde Pública. 2019;35(Suppl3):e00056619. https://doi. org/10.1590/0102-311X00056619

19. Vale D, Morais CMM, Pedrosa LFC, Ferreira MÂF, Oliveira ÂGRDC, Lyra CO. Spatial correlation between excess weight, purchase of ultra-processed foods, and human development in Brazil. Ciênc Saúde Coletiva. 2019;24(3):983-96. https://doi.org/10.1590/1413-81232018243.35182016

20. Satija A, Yu E, Willett WC, Hu FB. Understanding nutritional epidemiology and its role in policy. Adv Nutr. 2015;6(1):5-18. https://doi.org/10.3945/an.114.007492

21. Giovannucci E. Nutritional epidemiology: forest, trees and leaves. Eur J Epidemiol. 2019;34:319-35. https://doi. org/10.1007/s10654-019-00488-4

22. Ratan SK, Anand T, Ratan J. Formulation of research question: stepwise approach. J Indian Assoc Pediatr Surg. 2019;24(1):15-20. https://doi.org/10.4103/jiaps.JIAPS_76_18

23. National Libary of Medicine (United States). Medical subject headings 2020. Bethesda: NLM; 2020 [cited 2020 May 9]. Available from: https://meshb.nlm.nih.gov/search

24. Biblioteca Virtual em Saúde (Brasil). Descritores em Ciências da Saúde. Brasília: Biblioteca; 2020 [citado 9 maio 2020]. Disponível em: http://decs.bvs.br/

25. Cole TJ, Bellizzi MC, Flegal KM, Dietz WH. Establishing a standard definition for child overweight and obesity worldwide: international survey. BMJ. 2000 [2020 jun 18];320(7244):1240-3. https://doi.org/10.1136/bmj.320.7244.1240

26. World Health Organization. Physical status: the use and interpretation of anthropometry. Report of a WHO Expert Committee. Geneva: Organization; 1995.

27. World Health Organization. Obesity: preventing and managing the global epidemic. Geneva: Organization; 2000.

28. Centers for Disease Control and Prevention (United States). Childhood overweight and obesity. Atlanta: Centers; 2020 [cited 2020 May 6]. Available from: https://www.cdc.gov/obesity/childhood/index.html

29. World Obesity Federation. Obesity classification. London: Federation; 2020 [cited 2020 May 6]. Available from: https://www.worldobesity.org/about/about-obesity/obesity-classification

30. Alcaraz JPH, Ramírez JP, Peinado MEL. Actualizando los abordajes socioculturales de la obesidad: propuestas a partir de Hacking, Bourdieu y Foucault. Physis. 2020;30(3):e300322. https://doi.org/10.1590/s0103-73312020300322

31. Gracia Arnaiz M. La obesidad como enfermedad: la obesidad como problema social. Gac Med Mex. 2010;146(6):389-96.

32. Gracia-Arnaiz M, Demonte F, Kraemer FB. Prevenir la obesidad en contextos de precarización: respuestas locales a estrategias globales. Salud Colect. 2020;16:e2838. https://doi.org/10.18294/sc.2020.2838

33. Pinto MS, Bosi MLM. Muito mais do que pe(n)sam: percepções e experiências acerca da obesidade entre usuárias da rede pública de saúde de um município do Nordeste do Brasil. Physis. 2010;20(2):443-57. https://doi.org/10.1590/ S0103-73312010000200006

34. Araújo KL, Pena PGL, Freitas MCS. Sofrimento e preconceito: trajetórias percorridas por nutricionistas obesas em busca do emagrecimento. Ciênc Saúde Coletiva. 2015;20(9):2787-96. https://doi.org/10.1590/1413-81232015209.07542014

35. Seixas CM. Dimensões clínicas do ato na obesidade: compulsão por comer e sintoma na perspectiva psicanalítica. Psicol Estud. 2019;24:e40350. https://doi.org/10.4025/psicolestud.v24i0.40350

36. Tarozo M, Pessa RP. Impacto das consequências psicossociais do estigma do peso no tratamento da obesidade: uma revisão integrativa da literatura. Psicol Ciência Prof. 2020;40:e190910. https://doi.org/10.1590/1982-3703003190910

37. Bourdieu P. O poder simbólico. 14a. ed. Rio de Janeiro: Bertrand Brasil; 2006.

38. Kuhn TS. O caminho desde a estrutura. São Paulo: Unesp; 2006.

39. Poskitt EM, Cole TJ. Nature, nurture, and childhood overweight. Br Med J. 1978;1(6113):603-5. https://doi.org/10.1136/ bmj.1.6113.603

40. Cole TJ. Using the LMS method to measure skewness in the NCHS and Dutch National height standards. Ann Hum Biol. 1989;16(5):407-19. https://doi.org/10.1080/03014468900000532

41. Cole TJ, Flegal KM, Nicholls D, Jackson AA. Body mass index cut offs to define thinness in children and adolescents: international survey. BMJ. 2007;335(7612):194. https://doi.org/10.1136/bmj.39281.439178.80 
42. Freedman DS, Woo JG, Ogden CL, Xu JH, Cole TJ. Distance and percent distance from median BMI as alternatives to BMI z-score. Br J Nutr. 2019;23:1-8. https://doi.org/10.1017/S0007114519002046

43. Wright CM, Marryat L, McColl J, Harjunmaa U, Cole TJ. Pathways into and out of overweight and obesity from infancy to mid-childhood. Pediatr Obes. 2018;13(10):621-7. https://doi.org/10.1111/ijpo.12427

44. Dietz Jr WH. Childhood obesity: susceptibility, cause, and management. J Pediatr. 1983;103(5):676-86. https://doi. org/10.1016/s0022-3476(83)80457-0

45. Gortmaker SL, Must A, Perrin JM, Sobol AM, DietzWH. Social and economic consequences of overweight in adolescence and young adulthood. N Engl J Med. 1993;329(14):1008-12. https://doi.org/10.1056/NEJM199309303291406

46. Massetti GM, Dietz WH, Richardson LC. Excessive weight gain, obesity, and cancer: opportunities for clinical intervention. Jama. 2017;318(20):1975-6. https://doi.org/10.1001/jama.2017.15519

47. Flegal KM. Defining obesity in children and adolescents: epidemiologic approaches. Crit Rev Food Sci Nutr. 1993;33(4-5):307-12. https://doi.org/10.1080/10408399309527625

48. Flegal KM, Carroll MD, Kuczmarski RJ, Johnson CL. Overweight and obesity in the United States: prevalence and trends, 1960-1994. Int J Obes Relat Metab Disord. 1998;22(1):39-47. https://doi.org/10.1038/sj.ijo.0800541

49. Arroyo P, Loria A, Fernández V, Flegal KM, Kuri-Morales P, Olaiz G, et al. Prevalence of pre-obesity and obesity in urban adult Mexicans in comparison with other large surveys. Obes Res. 2000;8(2):179-85. https://doi.org/10.1038/ oby. 2000.19

50. Flegal KM, loannidis JPA. The obesity paradox: a misleading term that should be abandoned. Obesity. 2018;26(4):629-30. https://doi.org/10.1002/oby.22140

51. Flegal KM, loannidis JPA, Doehner W. Flawed methods and inappropriate conclusions for health policy on overweight and obesity: the global bmi mortality collaboration meta-analysis. J Cachexia Sarcopenia Muscle. 2019;10(1):9-13. https://doi.org/10.1002/jcsm.12378

52. Flegal KM, Graubard BI, Williamson DF, Gail MH. Excess deaths associated with underweight, overweight, and obesity: an evaluation of potential bias. Vital Health Stat 3. 2018;(42):1-21.

53. Oliver T. Post-mortem in a case of extreme obesity. J Anat Physiol. 1880;14(pt 3):345-7.

54. Colacco B. Obesity in a child. Ind Med Gaz. 1885;20(5):167.

55. Lyon DM. The problem of obesity. Edinb Med J. 1931;38(5):T73-T90.

56. Greene R. Adiposity. Postgrad Med J. 1946;22(248):169-81.

57. Cappon D. Obesity. Can Med Assoc J. 1958;79(7):568-73.

58. Billewicz WZ, Kemsley WF, Thomson AM. Indices of adiposity. Br J Prev Soc Med. 1962;16(4):183-8.

59. Cohen J. Obesity: a review. J R Coll Gen Pract. 1985;35(278):435-41.

60. Inoue Y, Qin B, Poti J, Socol R, Gordon-Larsen P. Epidemiology of obesity in adults: latest trends. Curr Obes Rep. 2018;7:276-88. https://doi.org/10.1007/s13679-018-0317-8

61. Ralston J, Brinsden H, Buse K, Candeias V, Caterson I, Hassell T, et al. Time for a new obesity narrative. Lancet. 2018;392(10156):1384-6. https://doi.org/10.1016/S0140-6736(18)32537-6

62. Chooi YC, Ding C, Magkos F. The epidemiology of obesity. Metabolism. 2019;92:6-10. https://doi.org/10.1016/j. metabol.2018.09.005

63. Blüher M. Obesity: global epidemiology and pathogenesis. Nat Rev Endocrinol. 2019;15:288-98. https://doi. org/10.1038/s41574-019-0176-8

64. Johnson TO. Prevalence of overweight and obesity among adult subjects of an urban African population sample. $\mathrm{Br}$ J Prev Soc Med. 1970;24(2):105 9. https://doi.org/10.1136/jech.24.2.105

65. Saldanha-Gomes C, Marbac M, Sedki M, Cornet M, Plancoulaine S, Charles M-A, et al. Clusters of diet, physical activity, television exposure and sleep habits and their association with adiposity in preschool children: the EDEN mother-child cohort. Int J Behav Nutr Phys Act. 2020;17(1):20. https://doi.org/10.1186/s12966-020-00927-6

66. Doom JR, Lumeng JC, Sturza J, Kaciroti N, Vazquez DM, Miller AL. Longitudinal associations between overweight/ obesity and stress biology in low-income children. Int J Obes. 2020;44(3):646 55. https://doi.org/10.1038/s41366-0190447-4

67. Keetile M, Navaneetham K, Letamo G, Bainame K, Rakgoasi DS, Lesego Gabaitiri L, et al. Socioeconomic and behavioural determinants of overweight/obesity among adults in Botswana: a cross-sectional study. Bmj Open. 2019;9(12):e029570. https://doi.org/10.1136/bmjopen-2019-029570 
68. Hoare E, Crooks N, Hayward J, Allender S, Strugnell C. Associations between combined overweight and obesity, lifestyle behavioural risk and quality of life among Australian regional school children: baseline findings of the Goulburn Valley health behaviours monitoring study. Health Qual Life Outcomes. 2019;17(1):16. https://doi. org/10.1186/s12955-019-1086-0

69. Abraham S, Nordsieck M. Relationship of excess weight in children and adults. Public Health Rep. 1960;75:263-73.

70. Wall JR, Pyke DA, Oakley WG. Effect of carbohydrate restriction in obese diabetics: relationship of control to weight loss. Br Med J. 1973;1(5853):577-8. https://doi.org/10.1136/bmj.1.5853.577

71. Cairney J, Ostbye T. Time since immigration and excess body weight. Can J Public Health. 1999;90(2):120-4. https:// doi.org/10.1007/BF03404114

72. Faeh D, William J, Tappy L, Ravussin E, Bovet P. Prevalence, awareness and control of diabetes in the Seychelles and relationship with excess body weight. Bmc Public Health. 2007;7:163. https://doi.org/10.1186/1471-2458-7-163

73. Steinmaus C, Castriota F, Ferreccio C, Smith AH, Yuan Y, Liaw J, et al. Obesity and excess weight in early adulthood and high risks of arsenic-related cancer in later life. Environ Res. 2015;142:594-601. https://doi.org/10.1016/j. envres.2015.07.021

74. Davis CL, Litwin SE, Pollock NK, Waller JL, Zhu H, Dong Y, et al. Exercise effects on arterial stiffness and heart health in children with excess weight: the SMART RCT. Int J Obes. 2020;44(5):1152-63. https://doi.org10.1038/s41366019-0482-1

75. James WP. Who recognition of the global obesity epidemic. Int J Obes. 2008;32(Suppl7):S120-6. https://doi. org/10.1038/ijo.2008.247

76. Hussain A, Mahawar K, Xia Z, Yang W, El-Hasani S. Obesity and mortality of COVID-19: meta-analysis. Obes Res Clin Pract. 2020;14(4):295-300. https://doi.org/10.1016/j.orcp.2020.07.002

77. Petrakis D, Margin D, Tsarouhas K, Tekos F, Stan M, Nikitovicet D, et al. Obesity: a risk factor for increased COVID-19 prevalence, severity and lethality (Review). Mol Med Rep. 2020;22(1):9-19. https://doi.org/10.3892/mmr.2020.11127 